\title{
Gerhardus Marthinus Maritz Pelser, hoogleraar 1972-1989
}

\author{
P B Boshoff \\ Universiteit van Pretoria
}

\begin{abstract}
Gerhardus Marthinus Maritz Pelser, professor 19721989

It is the aim of this article to discuss the essentials of the work of Gert Pelser. This is done under five headings: The historical Jesus and the kerygmatic Christ; Rudolf Bultmann; the canon; diachronic and synchronic readings of texts; biblical theology and dogmatic theology. This is done to shed light on Pelser's standpoints, and thus to show his expectations of a New Testament scholar. The conclusion is that he has not yet reached a complete awareness of the impact of his own work.
\end{abstract}

\section{INLEIDING}

Gert Pelser het op die ontwikkeling van die Nuwe-Testamentiese wetenskap, wat hy voltyds vanaf 1972 tot 1989 doseer het, ' $n$ beduidende invloed uitgeoefen. Hy was 'n toegewyde akademikus en het deur sy sterk persoonlikheid ook bygedra tot die praktiese voorbereiding van die studente tot die predikantsamp. In sy tyd was hy een van die uitstaande persoonlikhede van die Fakulteit. 'n Beoordeling wat net op sy geskrifte berus, kan nooit ' $n$ volledige prentjie van hom skets nie. Maar wanneer hier in breër verband 'n woord oor hom moet geskryf word, moet die persoonlike meer op die agtergrond tree en moet sy geskrewe woord die leidende rol speel. Tog verhoed dit ons nie om te stel dat die indruk wat hy op sy studente nagelaat het een van vernuwende denke was nie. Sy studente kon met 'n ruimer lewensuitkyk van die Universiteit af die lewe ingaan. Dit is die beste wat hy gegee het. 
In hierdie artikel word slegs die hoofsake van Pelser se werk aangedui en bespreek. Die kritiese bespreking sal veral om vyf temas beweeg. In sy wetenskaplike publikasies toon hy 'n ontwikkeling vanaf sy proefskrif (1971) tot waar hy sy teologiese tuiste vandag vind. Sy ontwikkeling is nie 'n klein verskuiwing nie - dit gaan om iets nuuts. Eintlik is dit net sy proefskrif wat die voorstadium uitmaak, terwyl die res van sy publikasies deel uitmaak van die vernuwing. Die mees taktvolle motief tot ' $n$ waardebepaling sou wees om dit te voltrek in terme van wat Pelser self aandui van ' $\mathrm{n}$ Nuwe-Testamentikus verwag kan word. Die voordeel van so 'n benadering is dat daar nie van 'n losstaande norm gebruik gemaak word nie, maar een wat homself aanbeveel. En 'n verdere winspunt is dat Pelser só op sy eie durf en daad aangewese bly. Verder as dit is nie nodig om te gaan nie, aangesien Pelser nog nie sy rol uitgespeel het nie. Hy was en is een van die sentrale manne in die Hervormde teologiese wêreld.

\section{DIE HISTORIESE JESUS EN DIE KERUGMATIESE CHRISTUS}

Die belangrike probleem van die Nuwe-Testamentiese teologie gaan oor die vraag of Jesus se verkondiging deel van die evangelie uitmaak of nie. Is die Christelike geloof gebaseer op Jesus se leer en die leer van die apostels of net op wat die apostels en die kerk verkondig het? Bultmann het die standpunt ingeneem dat die grondliggende onderskeid tussen Jesus se verkondiging en die verkondiging van die kerk nie misgekyk moet word nie. Paulus en Johannes het duidelik meer verkondig as Jesus. Die uitspraak, 'Iemand wat aan Christus behoort, is 'n nuwe mens. Die oue is verby, die nuwe het gekom' (2 Kor 5:17) kan nie terugverplaas word na die verkondiging van Jesus toe nie. Wanneer iets soortgelyks in die woorde of werke van Jesus gevind word, is so 'n interpretasie deur die boodskap of kerugma van die kerk gelei (Bultmann 1967:468). Om te verhoed dat die historiese Jesus meer betekenis kry as wat Hom toekom, beskryf Bultmann sy verhouding tot die kerklike dogma in terme van wet en evangelie. Die historiese Jesus het die wet verkondig terwyl die kerk die evangelie verkondig. Net waar die onderskeid tussen wet en evangelie reg verstaan word en die historiese Jesus by die wet ingedeel word, kan die kerklike evangelie tot sy reg kom (Bultmann in Jaspert 1971:185; vgl ook 64-65). Bultmann (1980:37) deel die verkondiging van die historiese Jesus by die Ou Testament in en verstaan ook die Ou Testament as uitdrukking van die voor-Christelike bestaan onder die wet. Die bestaan onder die wet word deur die kerklike verkondiging oorwin in die bestaan onder die evangelie.

Uit Pelser se werk blyk dat hy aanvanklik 'n hoë premie geplaas het op die terugvoering na Jesus self. Hy wil byvoorbeeld aan die himne in Filippense 2:6-11 
geen gnostiserende karakter toeken nie, omdat die ooreenkoms tussen die mite en die carmen Christi toevallig en niksseggend is. Jesus is eerder self die oorsprong van die sogenaamde mitiese skema van sy neerdaling of verhoging: 'Niemand op die aarde was al in die hemel nie behalwe Hy wat uit die hemel gekom het, naamlik die Seun van die mens. Moses het die slang in die woestyn hoog op 'n paal gesit; so moet die Seun van die mens verhoog word, sodat elkeen wat in Hom glo, die ewige lewe kan hê' (Joh 3:13-15; vgl Pelser 1971:16).

In verband met die Christologiese tradisie waarvolgens Jesus met sy opstanding tot 'Seun van God' verhoog is (Rom 1:3-4), meen Pelser dat Paulus se woorde hierdie indruk kan skep, maar dat dit tog nie die bedoeling is nie. Jesus het immers self met 'n uitspraak, soos die tempel wat $\mathrm{Hy}$ in drie dae weer sou bou (Joh 2:19), aangedui dat Hy reeds voor die opstanding die Seun van God is wat uit die dood kan opstaan (Pelser 1971:168).

Van sy eerste lesings wat Pelser na sy aanstelling as dosent aangebied het, het oor die Nagmaal gegaan. Wat hom van die Nagmaal en die doop, besonder geïnteresseer het, is die historiese, die ontstaan daarvan, wat daaragter sit. Wat is die verband tussen die tafelgemeenskap van Jesus met sy dissipels en die kerklike Nagmaal? Hierdie vraag is belangrik in die lig daarvan dat die kerk van die standpunt af uitgaan dat Christus dit ingestel het en dat die Nagmaal gebruik moet word soos Hy dit ingestel het. Die vraag ontstaan verder of Jesus self hierdie twee sakramente ingestel het. Wat sy gevolgtrekking betref, konkludeer Pelser (1974:148-149; vgl 1976:166-167) in verband met die Nagmaal dat die historiese Jesus nie die Nagmaal ingestel het nie. Paulus, wat volgens Pelser die oudste tradisie oor die Nagmaal weergee, 'kon bedoel' dat die oorlewering oor die Nagmaal na die historiese Jesus toe herlei kan word, maar dit is die verhoogde Christus wat die inhoud en betekenis van die kerklike Nagmaal waarborg. In verband met die doop stel Pelser (1981a: 114; 1981b:29-30; 1987b:559) dat die paasgebeure die begronding vir die doop is, dit wil sê dat die kerk nie doop omdat die historiese Jesus so 'n bevel gegee het nie, maar omdat die doop ingebed is in die kerklike boodskap van die gekruisigde en opgestane Christus.

Gaandeweg het Pelser dus wegbeweeg van die belangrike rol wat hy aan die historiese Jesus toegeken het, en word dit nie meer so belangrik wat Jesus self sou sê of dink nie (Pelser 1987a:183-185). Die kruis van Christus het heilsbetekenis, nie omdat Hy self so gedink het nie, en is nie af te lei uit wat Hy self gesê het nie, maar omdat dit so deur die kerk verkondig word. In die kerklike verkondiging ontmoet Christus se kruis en opstanding die mens as die moontlikheid van sy eie kruis en opstanding. 


\section{RUDOLF BULTMANN}

Rautenbach (1978:71) merk op dat die belangrikste saak op die agenda van die kerk in Suid-Afrika die kerk se betrokkenheid by sosiaal-politieke vraagstukke is. Die besinning oor die verkondiging van die evangelie aan die moderne mens word as ' $n$ onbelangrike saak op die agenda hanteer, 'meer in die kader van kennisgewing van mosie' (Rautenbach 1978:71). Rautenbach bedoel sy opmerking nie as 'n testimonium pauperis van die kerk en teologie nie, maar as die beskrywing van 'n toestand waarmee hy self voorasnog vrede het.

Pelser is een van die manne wat die botsing tussen die kontemporêre wêreldbeeld en die verouderde wêreldbeskouing van die Skrif te berde gebring het. Hy vertel dat hy gedurende sy doktorale studie deur prof van Rensburg aangeraai is om Bultmann se Theologie des neuen Testaments te lees. Tot in daardie stadium is na Bultmann net as ketter verwys. Pelser het met sy aanvanklike kennismaking met Bultmann nog 'n weerstand teen hom gehad, maar gaandeweg het hy besef dat hier ' $n$ teoloog is wat ' $n$ teks lees met die bedoeling om die teks vir die hede verstaanbaar te maak en in die hede iets te laat sê en te laat gebeur. Hy probeer nie net om proposisies na te sê en te herhaal nie.

'n Mens moet besef dat die bevraagtekening van gangbare voorstellings eintlik nie anders kan geskied as by wyse van 'kennisgewing van mosie' nie. Ongeduld kan die saak net bederf. Pelser (1987a:187) gee kennis van mosie deur Bultmann se ontmitologiseringsprogram, in die aflewering van die Henormde Teologiese Studies wat aan C H Rautenbach opgedra is, te evalueer:

Ek wil begin deur te stel dat Bultmann se volgehoue pogings om die Nuwe Testament, soos dit ook uit hierdie ondersoek duidelik geblyk het, vir die mens van vandag steeds geloofwaardig en verstaanbaar te maak, positief gewaardeer moet word. Dit is wel waar dat sommige van sy uitsprake vir die oor en gemoed wat gewoond is aan tradisionele teologiese of dogmatiese paradigmas skokkend klink, maar dan moet 'n mens jou afvra of dit nie juis nodig is nie.

Om die kerklike boodskap geloofwaardig vir moderne mense te vertolk, is dit noodsaaklike dat daar verstaanbaar van die mens gepraat moet word. Soos bekend, het Bultmann gemeen dat Heidegger die taal gevind het waarin die menslike bestaan verstaanbaar onder woorde gebring word. Die teologie kan hierdie filosofiese taal as uitdrukkingsmiddel gebruik om die boodskap van die kerk te formuleer. Dreyer (1966:42) het hierdie leen by die filosofie van Heidegger deur Bultmann as 'n boedeloorgawe van die teologie aan die filosofie beskryf. Pelser (1987a:176-177) ontken dat die eksegese op hierdie manier aan die filosofie uitverkoop word. Hy begrond dit deur aan te sluit by die argument dat die beskrywing van die wese van die 
menslike bestaan as eksistensie - dit wil sê dat die menslike lewe verwerklik word in die ontmoetings waarvoor hy oop is - nie sonder die Nuwe Testament gedoen is nie. Maar dit is ook nog nie van deurslaggewende belang nie. Die verhouding tussen filosofie en teologie, soos Bultmann dit verstaan, bestaan eerder daarin dat die filosofie die verskynsel van die mens se weiering om homself in die ontmoetings van die toekoms te vind, sy vervallendheid, kan beskryf, maar hom nie daaruit kan help nie. Die filosofie meen self dat hy die mens uithelp deur die term 'eksisteer' te omskryf. Maar volgens Bultmann is die mens daardeur nog nie gehelp nie; net die genade van God maak die mens oop en vry vir die toekoms. Die Nuwe Testament verkondig die heilsgebeure as hierdie bevrydende daad van God (Pelser 1987a:177; 1989b: 834).

Pelser fokus verder op die hart van Bultmann se teologie, naamlik die ontmitologisering van die Nuwe-Testamentiese eskatologie (Pelser 1989b; vgl 1989c). Eskatologie is by Bultmann nie die laaste hoofstuk van die dogmatiek wat oor die laaste dinge handel nie, maar die Christus-gebeure is eskatologies, die verkondiging van die Christelike eksistensie is eskatologies. 'In Jesus Christus as die eskatologiese gebeurtenis (Ereignis) het God 'n einde aan die ou wêreld gemaak. In die verkondiging wil die eskatologiese gebeurtenis telkens hede word, en in die geloof word dit telkens gebeurtenis' (Pelser 1989b:831). Pelser se voorganger in die leerstoel vir die Nuwe-Testamentiese wetenskap, prof S P J J van Rensburg, het nie waardering gehad vir die interpretasie wat Bultmann van die eskatologie gee nie:

As Bultmann die eskatologie aandui as 'ewigheid, hier en nou', dan lyk dit asof hy daarmee een of ander gerealiseerde eskatologie bedoel, of liewer 'n eskatologie wat sig in die hede van oomblik tot oomblik realiseer, waardeur die eskatologie beroof word van sy bybelse betekenis as die toekoms van ons Here Jesus Christus, as 'n toekomstige gebeure by die voleinding van die eeue.

(Van Rensburg 1967:113)

Van Rensburg voeg homself by die heilshistoriese standpunt waarvolgens die heilshandeling in Christus nie die volle heil bring nie, maar net in beginsel, sodat die volle heil in die geskiedenis nog moet ontvou: 'Die Christelike kerk wag nou in die tussentyd met groot verlange op die volle openbaring van hierdie godsheerskappy; want met die wederkoms van Christus sal die koningskap en die heerlikheid wat nou nog verborge is, in sy volle krag deurbreek' (van Rensburg 1967:111).

Van Rensburg (1967:120) meen dat die verkondiging die aandag moet vestig op die 'einddoel wat God het met die Skepping en die geskiedenis'. Hiervolgens is die verkondiging bloot 'n verwysing na die heil en nie self deel van die heilsgebeure nie. Van Rensburg verwag 'n spesifieke gebeurtenis êrens in die toekoms. Dat Christus 
die verwagte wending gebring het en dat die mens deur die prediking voor die vraag gestel word of hy hierdie wending vir sy eie lewe aanvaar, kom nie by hom na vore nie. Pelser (1989b:836) daarenteen, verstaan die verkondiging as deel van die heilsgebeure self, want die Christusgebeure word daarin hede, vir die gelowige tot heil en die ongelowige tot onheil. Christus kom telkens na vore in die woord wat Hom verkondig. Die kerk is die plek waar die verkondiging geskied en daarom is die kerk deel van die eskatologiese heilsgebeure. Die Gees is enersyds Christus self wat in die verkondiging by sy gemeente is en andersyds die lewe in gehoorsaamheid aan hierdie boodskap.

Wolmarans (1945:7) hou vas aan die objektiverende opvatting van heil en onheil en vra: '[W]aar sal die mens wat in ongeloof sterf vir sy sondes betaal vir sover hy hier op aarde nie betaal het nie? Die antwoord kan alleen wees: In die hel, want so leer die Skrif ons en dan is dit 'hel' in die betekenis van gehenna, hades, sheol en graf almal saam.'

Engelbrecht verstaan die verhewenheid van God lokaal en nie in die sin dat die mens nie oor God beskik nie. Hy sê van die gelowige dat hy 'onmiddellik na sy sterwe by en met Christus is en geestelik alreeds die geluksaligheid geniet' (Engelbrecht 1982:121). Die ongelowige gaan 'soos Judas, "na sy eie plek", die hel [Hand 1 vers 25]'. Pelser (1989b:836) betrek die openbaring van God op die menslike bestaan en voer aan dat die oordeel dieselfde is as die nie-aanvaarding van die verkondiging van Christus en dat die lewe in ongeloof die hel is, terwyl die lewe in geloof die hemel is.

Bultmann se teologie leef van die insig dat die teologie nie van die openbaring van God opsigself kan praat nie, maar net in soverre die menslike eksistensie daardeur bepaal word. Beukes (1979:90) vind fout hiermee: 'As sterk hermeneutiese beginsel het nog altyd gegeld: Wat sê die perikoop, wat sê die teks? Vir Bultmann is dit nie die belangrikste nie. Vir hom is die belangrikste: Wat sê die perikoop of die teks vir my as mens van hierdie tyd.' Vir Beukes moet die teks sy sê sê sonder om die konkrete mens aan te spreek. Dit sou beteken dat die mens 'n toeskouer van die openbaring van God kan wees. Bultmann sien die mens nie in so 'n rol nie, want volgens hom kan die mens net van God weet as hy weet van die aanspraak wat God op hom maak. 'Elke objektiewe of neutrale uitspraak oor God is 'n ontkenning van ons eksistensiële bepaald-wees deur God, van ons aangespreek wees deur God' (Pelser 1987a:177).

Waar geloof verstaan word as 'n toestand van gelowig wees, van persoonlike oortuiging en ervaring, en die voorwerp van die geloof uit die oog verloor word, kom daar 'n spanning tussen geloof en hoop. Vanuit so 'n 'sielige houding' (Pelser $1989 \mathrm{~b}: 825,836$ ) word die beswaar teen Bultmann ingebring dat hy die 'toekomspers- 
pektief van die eskatologie' laat vervaag (Van Rensburg 1967:113). Geloof word só beperk tot 'n bepaalde toestand, terwyl die hoop gerig moet wees op dit wat nog in die toekoms moet kom. So het Bultmann dit nie verstaan nie. Hy sien hoop as sinoniem met geloof, want geloof is nie 'n houding nie, maar gerig op die toekoms (Bultmann 1980:320). Die gelowige is oop vir die toekoms wat God vir hom het. Hoop is hierdie openheid vir die toekoms (Pelser 1989b:831, 836).

\section{DIE KANON}

Pelser (1988) skryf 'n artikel met die titel 'Die kanon in die kanon as hermeneutiesteologiese probleem'. Reeds die titel moet 'n mens laat vermoed dat dit gaan om 'n verkenning, 'n probleemstelling. Die toon van die skrywe is nie dié van iemand wat meen dat hy reg het nie, maar iemand wat vra en na antwoorde soek, in plaas van om te sê hoe dit staan, sonder om dit nodig te vind om verder te vra. Hier is iemand aan die woord wat voor 'n probleem te staan gekom het en hy wou die sake nie mooier stel as wat dit is nie. Hy het nie self die probleem uitgedink nie - dit het vir hom duidelik geword uit wat hy raakgesien het. Niemand sal van 'n kritiese opname en gesprek oor hierdie aangeleentheid meer verwag as hy self nie. Daarom sal'n veroordeling van die skrywer net so min van pas wees as 'n verswyging van die saak wat hy aan die orde stel. 'n Mens moet verder in gedagte hou dat Pelser se bevindinge nie so vreemd in Hervormde geledere behoort te klink nie, aangesien Artikel I van die Kerkwet en Bepalings neerlê: 'Die Nederduitsch Hervormde Kerk van Afrika grond hom op die Bybel as Woord van God' (NHKA 1989:1) - 'n standpunt wat maklik uitgebou kan word om met Pelser se posisie ooreen te stem.

Pelser se werk aan die Nuwe Testament het dit vir hom duidelik laat word dat die verskeidenheid van die Nuwe-Testamentiese getuienisse ten ene male nie te harmoniseer is nie. Dit geld vir temas soos die Christologie, ekklesiologie, pneumatologie, doop en Nagmaal, wat onder die breë term van Nuwe-Testamentiese teologie ter sprake gebring kan word (vgl Pelser 1986:43; 1987b:558-563). Daar is nie net 'n verskeidenheid van opvattings oor 'n bepaalde tema in die Nuwe Testament nie, maar daar kan ook 'n ontwikkeling van 'n bepaalde tema aangedui word: Watter opvatting uit die verskeidenheid is geldig of watter stadium in die ontwikkeling is toonaangewend? (vgl Pelser 1985). Die Nuwe Testament is verteenwoordigend van verskillende vroeg-kerklike sentra of teologiese rigtings sonder dat een die deurslaggewende rol speel (Pelser 1988:392).

Pelser (1988:392) sluit hom aan by dié mening en beklemtoon dit dat die kerk in 'n 'permanente krisis' gedompel is deur die spanning wat ontstaan as gevolg van die norm van die verkondiging wat nie eenduidig is nie. Onder so 'n krisis moet 'n 
mens verstaan dat die tyd ryp is om 'n beslissing te neem, maar dat dit nie gedoen word nie en gedoen kan word nie. Die einde van die kritiese toestand is nie in sig nie. Die rede vir hierdie onsekerheid lê daarin dat die kanon, wat volgens hom as norm van die verkondiging moet geld, 'n verskeidenheid van geleentheidgeskrifte huisves, wat in hulle verskeidenheid en teenstrydighede nie 'n eenduidige norm vir die uitleg van die Skrif aanbied nie. As norm bring die kanon nie eenheid nie, maar legitimeer dit eerder die bestaan van die veelheid van denominasies as die eenheid van die kerk, aldus die beroemd geworde uitspraak van Käsemann (Pelser 1988:391; Käsemann 1970a:131).

Pelser (1988:399) gee toe dat dit na 'n hopelose uiteenlopendheid lyk as al die kerke en denominasies deur die erkenning van die kanon gelegitimeer word. Maar self waardeer hy dit positief: 'Dit hou minstens ook die voordeel in van 'n voortgaande teologiese debat, kritiek en selfkritiek, wedersydse bevrugting en gevolglike teologiese kreatiwiteit en ontwikkeling' (Pelser 1988:398; vgl 1989d:447). Hy beklemtoon dat elkeen sy verstaan gegun moet word. Selfs as dit dan relatiwiteit of opportunisme genoem word, staan hy daarby. Daar is verskillende verstaansmoontlikhede en elkeen moet met verantwoordelikheid probeer verstaan met die middele wat tot sy beskikking is. Elkeen moet egter kan rekenskap gee van waarmee hy besig is. Die resultate moet intersubjektief gedeel word met mense wat dit teologies wil deurdink. Op hierdie wyse word daar naderhand 'n groep gevorm.

Pelser (1988:395-398) beredeneer die kwessie van die Sachmitte in die kanon, dit wil sê die middelpunt van waarom dit in die kanon gaan en wat kan dien as kriterium vir die keuse van 'n kanon in die kanon. So 'n kriterium word uit die kanon self geneem en word gebruik om die geskrifte van die Nuwe Testament daaraan te toets. Pelser wil egter nie self 'n middelpunt vir die Nuwe Testament aanvaar nie, want dit sou dan uiteindelik weer beteken dat alle verstaan van die getuienis van die Nuwe Testament uiteindelik dieselfde gaan sê (Pelser 1988:400). Op Käsemann se keuse van die iustificatio impii as die Sachmitte sou Pelser byvoorbeeld die kritiek inbring dat dit nie die middelpunt van die Nuwe Testament vorm nie, maar dalk van Paulus. Dit kan nie by al die korpusse van die Nuwe Testament ingebring word nie en sal dus neerkom op 'n verenging van die kanon (vgl Pelser 1988:395). Pelser meen dat die iustificatio impii dus nie kan dien as 'n teologiese gemene deler vir die totaliteit van die Nuwe Testament nie en dat so 'n gemeenskaplike noemer nie aangetoon kan word nie. Die enigste moontlikheid om by so 'n middelpunt uit te kom is om dit so algemeen te stel dat dit Jesus Christus is. Maar die oomblik as daar meer oor die persoon en werk van Jesus gesê moet word, kom die veelvuldigheid weer na vore, byvoorbeeld Jesus die profeet of Jesus die groot Hoëpriester en Jesus 
die gekruisigde of die geïnkarneerde. So word die navorser weer na die beginpunt, die rykdom en verskeidenheid van die Nuwe Testament toe teruggelei.

Vir die gang van die gesprek met Pelser is dit nodig om op te merk dat hy tog nie die hoop dat daar dalk 'n gemeenskaplike saak gevind kan word heeltemal opgee nie. Daar sal gekyk moet word na wat teologies en eksistensieel haalbaar is. Hy vra: 'Hoe kom ons by die "Sachmitte" uit?' en 'Hoe kontroleer ons hierdie soeke?' (Pelser 1988:396, 397).

Miskien is dit die beste om die gesprek by Käsemann te laat begin. Hy het immers die rigting aan die gang gesit waarin Pelser ook gaan. En deur hier te begin word dit ook duidelik dat dit nie gaan om nuwe gedagtes of selfs argumente waarvan Pelser nog nie kennis geneem het nie. Käsemann het sy aanvanklike stelling dat die kanon nie die eenheid van die kerk begrond nie, maar alle konfessies legitimeer selfs nog verder verskerp: 'Er legitimiert als solcher auch mehr oder weniger alle Sekten und Irrlehrern' (Käsemann 1970b:402). Maar by hierdie vasstelling wou hy nie berus nie, hy wou juis daarmee aantoon dat die kanon nie die norm vir die verkondiging kan wees nie. Alles kan uit die Skrif bewys word en is al bewys, daarom kan die tota scriptura nie die norm wees nie, maar moet daar onderskei word. Käsemann wil die verhouding eerder omkeer: Nie die kanon is die norm vir die verkondiging nie, maar die verkondiging is die norm vir die kanon. Indien die kanon, as refleksie van die kerkgeskiedenis, die norm sou wees, sou dit beteken dat Christus in die kerkgeskiedenis opgaan en verdwyn en nie meer Here van die kerk kan wees nie. Hy sou dan nie meer teenoor die kerk staan nie, maar daarmee geïntegreer wees.

Pelser (1988:399) verstaan dat die openheid van die kanon in sy verskeidenheid geleë is, maar gee dan aan die verskeidenheid 'n dwingende karakter. Die versameling van verskeidenhede vorm ' $n$ laaste norm wat in werklikheid nie meer oop is nie, maar geslote. Die meerduidigheid vorm 'n sisteem wat aanvaar moet word. Maar as die kanon van die Nuwe Testament oop is, beteken dit dat die kanon self nie afgesluit is nie, nie ' $n$ afgeronde sisteem vorm nie. Die oop karakter van die kanon beteken dat dit op sigself nie genoegsaam is nie. Die kanon kan nie self die norm wees nie, maar vra om 'n norm. Die kanon in sy verskeidenheid is nie self boodskap nie, maar staan in diens van 'n boodskap. Die kanon is oop, na die boodskap toe. Die hele kanon is beskikbaar vir die boodskap.

Hiermee is reeds aangedui waar die eenheid te midde van die verskeidenheid en meerduidigheid te vind is, naamlik in die boodskap, die evangelie, die dogma, die verkondiging, die geloof. Hierdie eenheid is nie die eenheid van 'n teologiese noemer wat alles kan insluit nie. Die evangelie is nie dieselfde as teologie nie. Die verskillende teologieë gee uitdrukking aan die een evangelie. Paulus verkondig met sy 
regverdigingsleer dieselfde evangelie as die engel in die kersverhaal: 'Moenie vrees nie, want ek verkondig aan julle 'n groot vreugde, wat die hele volk sal ervaar: Vandag is vir julle in die Stad van Dawid 'n Redder gebore, naamlik Christus, die Here. En dit is vir julle die teken: Julle sal 'n kindjie vind wat in doeke toegedraai is en in 'n krip lê' (Luk 2:10-120).

Die eenheid van die verlossingsgebeure word deur die woord uitgebring, want die woord vertel nie net van die heil nie, maar maak die aanbod van heil. Pelser (1989b:836; vgl 1980:60; 1987a:181-185) stel self 'dat Christus as die gekruisigde en opgestane Hom slegs in die Woordverkondiging laat ontmoet, nêrens anders nie'. Die woord van heil gaan aan alle Christologieë vooraf. Die gelowige glo een saak: dat hy met God versoen is. Die aanspraak wat God maak, vra van die mens nie dit of dat nie, maar sy hele lewe.

Dit is dan ook nie verkeerd om in hierdie opsig van 'n dogmatiese waarheid te praat as die ontwerp wat ten grondslag moet lê van die eksegese nie. Solank 'n mens net nie hieronder 'n statiese dogmatisme verstaan wat 'n vreemde dogma aan die tekste by die uitleg daarvan opdring nie. Dogma verwys na 'n bepaalde heilsdaad van God, maar nie as handeling opsigself nie, eerder as handeling aan die mens waarin die mens homself nuut verstaan. Dogma is 'n verklaring: Dogma verklaar aan die mens hoe dit om hom staan, wat die waarheid van sy lewe is en verwag van die mens om stelling in te neem (vgl Schmithals 1980:177). Die kanon moet gesien word as die produk van die dogma. Daarom moet die dogma veronderstel word by die ondersoek van die Skrif en moet dit ook na vore kom as die resultaat van die Bybelondersoek.

Pelser (1988:400) keur die gebruik van een hermeneutiese sleutel af, want '[d]it sal die teologie dood maak'. Hy vrees dat dit eentonig sal wees. 'n Mens sou wou vra of hierdie opmerking nie heimlik op die opvatting van geloof as die aanvaarding van 'n hoeveelheid leerstukke berus nie? Maar nog belangriker is die vraag of die boodskap van verlossing, byvoorbeeld nader beskryf as die regverdiging deur die geloof, wat in werklikheid revolusionêr is, ooit eentonig kan wees? 'n Mens moet dit net nie losmaak van die gebeure waarvan dit 'n aanduiding wil wees nie en dit as 'n losstaande stelling opvat nie.

\section{DIACHRONIES EN SINCHRONIES}

Tydens Pelser se dosentskap het die strukturele benadering tot taal sterk na vore gekom. Volgens hierdie benadering moet die betekenis van 'n teks langs 'n sinchroniese weg eerder as 'n diachroniese verstaan word. Die geskiedenis rondom 'n teks is onseker, daarom moet daar op die sintaksis, die styl en semantiek van die teks 
gekonsentreer word om dit te verstaan. Pelser het homself in hierdie benadering ingewerk en 'n artikel oor 'Die aktante-model van A J Greimas' (Pelser 1983a) geskryf. Op die ou end staan hy verleë oor wat die verhouding tussen die teksimmanente benadering en die historiese benadering moet wees. Beoefenaars van die sinchroniese benadering verklaar dat die diachroniese nie weggegooi moet word nie, dat dit kan help om 'n teks te ontsluit (vgl du Toit 1980:122), maar niemand slaag daarin om die rol van die historiese benadering ten opsigte van die teksimmanente benadering uit te spel nie. Pelser (1983a:54-56; vgl 1980:54-55; 1983b:159-160; 1984:267-268) wil die klem eerder op die historiese benadering lê sonder om die belangrikheid van die struktuur van 'n bepaalde teks uit die oog te verloor. In hierdie verband is dit vreemd dat hy in sy verklaring van die Bybel dit nie waag om byvoorbeeld die historiese situasie van die ontvangers van die brief aan die $\mathrm{He}$ breërs in te kleur nie. Daar is 'n dreigende afvalligheid van die oorgelewerde belydenis in die gemeentelike lewe te bespeur, maar wat die oorsaak hiervan was, wil Pelser (1989a:310, 315) nie aandui nie. Indien hy 'n voorstel oor wat die oorsaak was, wou maak en dit aan die teks beproef, kon dit sy uitleg van die brief aansienlik verander en verdiep het.

Om sy eie teologiese arbeid meer bewustheid te gee en te integreer, sou dit vir Pelser gerade wees om meer duidelikheid te kry oor die historiese benadering, veral in die lig daarvan dat hy hom so met Bultmann vereenselwig. Vir Bultmann kan eksegese nie losgemaak word van wat 'n mens onder geskiedenis begryp en verstaan nie, geskiedenis waarin 'n mens self ook staan. Die eksegeet kan nie wegkom van die vraag wat die betekenis van geskiedenis is, dit wil sê van 'n lewe in geskiedenis of in ontmoeting nie (Bultmann 1968:228). Wat is die werklikheid van die geskiedenis, die geskiedenis soos dit in die teks verwoord is, en hoe word hierdie werklikheid vandag weer werklikheid? Die werklikheid van die teks van die Nuwe Testament is die evangelie, die regverdiging van die goddelose. As verstaan die afstand van die tyd wil oorbrug, moet die vergange werklikheid weer werklik word. Die vergange moontlikhede van die menslike eksistensie moet weer moontlikhede word. In hierdie sin aanvaar Bultmann (in Jaspert 1971:182) 'den Begriff der Existenz als meinen Kanon'. Die vraag na die eksistensieverstaan soos dit in die teks verwoord is, is van die begin af die vraag aan die teks. As die teks nie daarna gevra word nie, sal dit ook nie 'n antwoord hierop gee nie. Binne die histories-kritiese eksegese is die eksistensiebegrip die riglyn wat die ondersoek lei.

'n Mens kan tekste uit 'n estetiese oogpunt beskou en hulle innerlike en uiterlike struktuur aanteken. Maar sou 'n mens nie kon sê dat die eintlike wese van die mens, volgens die estetiese benadering, geleë is in sy vermoë om met sy intellek vorm aan stof te gee nie? Die wese van die mens is nie dat hy in ontmoeting eksis- 
teer nie, maar dat hy vorm kan gee, orde kan skep. Bultmann gaan van die standpunt uit dat alle tekste (veral filosofiese, godsdienstige en digterlike tekste), ook met die oog op die moontlikhede van menslike eksistensie wat daarin voorkom, ondersoek kan word. Dit is die perspektief van waaruit die Bybelse teks benader word. Die mens vra na homself as hy na geluk, heil, sin vra. In die antwoord wat die teks op hierdie vraag gee, word die eksegeet se selfverstaan op die spel geplaas en kan hy die aanspraak wat die teks maak, hoor (Bultmann 1968:228).

\section{BYBELSE TEOLOGIE EN DOGMATIESE TEOLOGIE}

Pelser (1983b:155-157) vestig die aandag op die Heilige Skrif as die objek wat bestudeer word in die Bybelse teologie. Die tekste van die Bybel moet verstaan word. Teologie is die verklaring van die Heilige Skrif. Die saak wat deur die Bybel voorgedra word, moet aan die orde gestel word. Sover vasgestel kon word, gee hy nêrens 'n duidelike omskrywing van die saak waarvan die Bybel getuienis aflê nie. Daar is immers nie eenstemmigheid oor wat hierdie saak is nie. As die Bybel die oorkonde van die heilsdaad van God in Christus is, is die saak, dit wil sê die voorwerp van ondersoek Jesus Christus. Die Bybel kan ook gelees word met die oog op die tekening van die vroeë Christendom in sy wording en verskeidenheid. In hierdie geval is die kerk in sy verskeidenheid die saak waarna die Bybel gevra word. Dit lyk of Pelser die saak van die Bybel eerder in die rigting van die tweede moontlikheid wil bepaal.

Naas die Bybelse teologie ruim Pelser (1985:348-349) 'n plek in vir die dogmatiese teologie. Die dogmatiek volg op die eksegese en neem die resultate van die Bybelverklaring verder. Die dogmatiek verlaat as ' $t$ ware die bodem van die teks en 'filosofeer' daaroor om normatiewe uitsprake vir die hede te maak. Dit is ook die gangbare opvatting van die verhouding tussen dogmatiek en eksegese, wat Pelser so verwoord. Miskien is dit die rede waarom daar so 'n groot gaping tussen eksegese en prediking is. Die preek kom op 'n groot distansie weg van die teks te staan. Pelser (1985:347) voel hierdie probleem aan en stel dat die eksegeet nie kan volstaan deur van die teks vas te stel 'what it meant' nie, hy moet deurdruk tot by 'what it means'. Die eksegese word in die verkondiging vrugbaar. Kan die punt van wat dit nou beteken egter bereik word sonder dat daar van die veronderstelling uitgegaan is dat die teks 'n aanspraak het om op die menslike selfverstaan te maak? En veronderstel dit nie al dogma voor en saam met die eksegese nie? 


\section{SLOTOPMERKING}

Omdat Pelser se werk nog onafgeslote is, het ek die gevoel dat daar nie van my 'n laaste bindende evaluering verwag is nie. Wat hier aangebied word is eerder riglyne vir 'n kritiese gesprek by die halfpadmerk. Die dringendste sake in verband met Pelser se teologiese werk is aangeraak en verborge probleme-is aan die lig gebring, veral met betrekking tot sy hantering van die kanonvraagstuk en sy Bultmannresepsie. Vrae wat nog beantwoord moet word, is: Gaan ek nie te ver nie? Wil ek Pelser dryf tot gevolgtrekkings wat hy nie wil maak nie en nie nodig het om te maak nie? Indien my gesigspunte geregverdig is, kan die saak inhoudelik verder gevoer word.

\section{Literatuurverwysings}

Beukes, M J du P 1979. Kategese en eksistensieteologie. HTS 35/1 \& 2, 88-100.

Bultmann, R [1960] 1967. Das Verhältnis der urchristlichen Christusbotschaft zum historischen Jesus, in Dinkler, E (Hrsg), Exegetica: Aufsätze zur Erforschung des Neuen Testaments, 445-469. Tübingen: Mohr.

--- [1950] 1968. Das Problem der Hermeneutik, in Bultmann, R, Glauben und Verstehen II, 211-235. Tübingen: Mohr.

--- 1980. Theologie des Neuen Testaments. 8. Aufl. Tübingen: Mohr.

Dreyer, P S 1966. Die wysgerige antropologie en die teologie, in Cronje, G (red), Die wysgerige antropologie en die menswetenskappe, 33-44. Pretoria: Van Schaik.

Du Toit, A B 1980. Die praktyk van die eksegese in die lig van nuwere wetenskaplike ontwikkeling, in Die Nuwe-Testamentiese wetenskap vandag. Uitgegee deur die departemente Nuwe Testament (A \& B) en Grieks, Universiteit van Pretoria.

Engelbrecht, B J [1963] 1982. Wat leer die Bybel ons oor die doderyk en hel, in Versamelde opstelle, Deel 3, 116-122. Pretoria: Universiteit van Pretoria.

Jaspert, B (Hrsg) 1971. Karl Barth-Rudolf Bultmann Briefwechsel 1922-1966. Zürich: Theologischer Verlag. (Karl Barth Gesammtausgabe V, 1.)

Käsemann, E [1951] 1970a. Begründet der neutestamentliche Kanon die Einheit der Kirche?, in Käsemann, E (Hrsg), Das Neue Testament als Kanon: Dokumentation und kritische Analyse zu gegenwärtige Diskussion, 124-133. Göttingen: Vandenhoeck.

--- 1970b. Zusammenfassung, in Käsemann, E (Hrsg), Das Neue Testament als Kanon: Dokumentation und kritische Analyse zu gegenwärtige Diskussion, 399-410. Göttingen: Vandenhoeck.

Nederduitsch Hervormde Kerk van Afrika 1989. Kerkwet en Bepalings. Pretoria: NHKA. 
Pelser, G M M 1971. Die carmen Christi Fil 2:6-11: 'n Eksegeties-Christologiese ondersoek. Ongepubliseerde DD-Proefskrif, Universiteit van Pretoria.

--- 1974. Die nagmaal by Markus en Paulus: 'n Vergelykende studie. HTS 30, 138149.

--- 1976. Die nagmaal by Paulus - geestelike voedsel en drank? HTS 32, 161-167.

--- 1980. Nuwere ontwikkelinge in die ondersoek van die tema 'geregtigheid van God' by Paulus, in Die Nuwe-Testamentiese Wetenskap vandag. Uitgegee deur die departemente Nuwe Testament (A \& B) en Grieks, Universiteit van Pretoria.

-.- 1981a. The objective reality of the renewal of life in Romans 6:1-11. Neotestamentica 15, 101-117.

--- 1981b. Die doop in die Nuwe Testament. Ongepubliseerde lesings, Universiteit van Pretoria.

--- 1983a. Die aktante-model van A J Greimas. HTS 38, 35-57.

--- 1983b. Objek en metode in die Bybelse teologie, in Dreyer, P S (red), Objek en metode in die geesteswetenskappe, 153-172. Pretoria: Universiteit van Pretoria.

--- 1984. Die Pauliniese soteriologie, in Du Toit, A B (red), Die Pauliniese briewe: Inleiding en teologie, 256-281. Pretoria: NG Kerkboekhandel. (HNT V.)

--- 1985. Die verhouding Bybelse teologie en dogmatiese teologie. HTS 42, 515533.

--- 1986. Resurrection and eschatology in Paul's letters. Neotestamentica 20, 3646.

--- 1987a. Die ontmitologiseringsprogram van Rudolf Bultmann. HTS 43, 162-191.

--. 1987b. Temaprediking uit die Nuwe Testament. HTS 43, 556-565.

--- 1988. Die kanon in die kanon as hermeneuties-teologiese probleem. HTS 44, 8-403.)

--- 1989a. Die brief aan die Hebreërs. Verklarende Bybel, 310-328. Kaapstad: Lux Verbi.

--- 1989b. Rudolph Bultmann se ontmitologisering van die Nuwe-Testamentiese eskatologie. HTS 45, 815-842.

--- 1989c. Rudolf Bultmann's programme of demythologizing and the resurrection narratives in John. Neotestamentica 23, 269-286.

--- 1989d. Die Bybel aan die universiteit en in die kerk. HTS 45, 442-450.

Rautenbach, C H 1978. Die toekoms van die kerk in die samelewing: Kollig op die sosiaal-etiese, insluitende politieke afmetings van Christelike kerk-bly in SuidAfrika, in Vorster, W S (red), Church and society/Kerk en samelewing, 68-97. Pretoria: Unisa. 
Schmithals, W 1980. Die theologische Antropologie des Paulus: Auslegung von Röm 7, 17-8,39. Stuttgart: Kohlhammer. (Urban-Taschenbücher/Kohlhammer Taschenbücher 1021.)

Van Rensburg, S P J J 1967. Die sin van die Nieu-Testamentiese Eskatologie. HTS 23/4, 108-120.

Wolmarans, H P 1945. 'En neergedaal na die hel toe' (Godsdienswetenskaplik gesien). Woord en waarheid: Tydskrif vir teologie en aanverwante vakke 2/1, 4-7. 